\title{
MYBL1 wt Allele
}

National Cancer Institute

\section{Source}

National Cancer Institute. MYBL1 wt Allele. NCI Thesaurus. Code C53083.

Human MYBL1 wild-type allele is located in the vicinity of $8 \mathrm{q} 22$ and is approximately $51 \mathrm{~kb}$ in length. This allele, which encodes myb-related protein $\mathrm{A}$, is involved in the regulation of transcription by RNA polymerase II as well as proliferation and differentiation of neurogenic, spermatogenic and B-lymphoid cells. 